\title{
A POSSIBLE RECORD OF COMMON POCHARDS FOR SOUTHERN SASKATCHEWAN
}

\section{FRANK BRAZIER, 2657 Cameron Street, Regina, Saskatchewan S4T 2W5}

Stonybeach Lake is a fairly large body of water about 8 miles north of Belle Plaine. Having no outlets, it is, actually, an extensive prairie slough. At the time of the topographical survey of 1882 it covered about 170 acres of Section 11, Township 18, Range 24 west of the Second Meridian, although the area fluctuates considerably with precipitation.

On the north shore a dugout has been excavated, the spoil being piled on the east and west sides. In 1977 the lake was very high and it had reached beyond the dugout, flooding it and the pasture for a considerable area. Waterfowl and shorebirds abounded.

On June 11, 1977, Elmer Fox and I were exploring the pasture and the slough on the north side. Elmer was investigating the vegetation on top of the eastern spoil bank while I had waded across the flooded area to the south of the dugout to reach a small dry area where a colony of Avocets was nesting. Returning, I heard a strange cry and, turning, saw a pair of ducks which resembled scaup on the dugout. At that moment the hen repeated the cry that first got my attention.

It was a fine day with bright sunshine and little wind. The birds were perhaps a hundred feet away. In my glasses $(10 \times 50$ power) I noticed the hen's whitish face markings and her unusual bill pattern, all bluish except for the black nail and black base. But the drake! Imagine a Greater Scaup with a brown head and the same kind of bill pattern as the hen. As I stared at them, I mentally went through all the pochards with which I was familiar Lesser Scaup? these birds were too large, had rounded heads, and the head colour was wrong; Redhead? right size and shape but the drake's light coloured body (similar to that of a (anvasback) and brown head were radically different from the brownish red head and dark grey body of a Redhead drake which also has a dark bill; Canvasback? head colour close enough but the sloping profile of the head was absent; Greater Scaup? about the right size but wrong hear colour and wrong bill pattern; Ring necked Duck? wrong bill pattern, hear colour, body pattern and size.

I called to Elmer but he was out o sight on the far side of the eastern spoi bank and did not hear me, so I waded over to get him. Then we both examined them. The drake had a smal patch on its body which suggested tc Elmer that molting had begun, but he could offer no solution to the bird' identity.

Back home that afternoon I sear ched through all my North Americar bird books, without success. It was no until I opened my old Field Guide to the Birds of Britain and Europe that found them - a male and female Common Pochard (Aythya ferina). Searching further I found the female' voice described as a harsh, growlin: "kur-r-r" while the female Redhear utters a coarse "kurr-kurr-kurr", much like the female Common Pochard. ${ }^{34}$

I was interested to note tha Dement'ev et al consider the Redheac and the Common Pochard to be 
conspecific, and that Palmer considers the Canvasback to be the nearest in the Nearctic, in total biology, to the Pochard of the Palearctic.' ${ }^{4}$ The species is found over a large part of central and northern Europe and Asia. ${ }^{4}$

I telephoned several birders but, as it was Saturday afternoon, I was unsuccessful in raising anyone; they were, I suppose, all out looking for rare birds. I reached Bob Luterbach on June 12, and he arranged with Frank Switzer (who has a 1000-mm telephoto lens for his camera) to visit Stonybeach Lake on the following Wednesday morning, but, due to prior commitments, they had to be in position very early. While they found two scaups on the dugout which soon flew away, the light was too poor for photography.

Bob Luterbach had pointed out to me that the Common Pochard is the only pochard with a red eye. I discovered from Palmer that the eye is red only in winter, becoming brownish orange in the spring. ${ }^{4}$ I returned twice to Stonybeach Lake with a telescope hoping to determine eye colour but, although I found the birds on the dugout each time, I was never able to see them well enough, nor did I ever see them in flight to check the wing stripe.

Godfrey does not list it for Canada; there are some Alaska records. ${ }^{2}{ }^{4}$

Neither Elmer nor I got back to the lake again. In the end we were left with our own observations, initially under excellent conditions, except for distance, when we saw two birds which agreed in every detail with the pictures of a male and female Commion Pochard.

'DEMENT'EV et al. 1952. Birds of the Soviet Union, Vol. 4. Moscow.

${ }^{2}$ CODFREY, W. E. 1966. The birds of Canada. Nat. Mus. Canada, Ottawa. Bull. 203.

${ }^{3}$ HOLLOM, P. A. D. 1962. The popular handbook of British birds. H. F. \& G. Witherby Ltd., London.

${ }^{4}$ PALMER, R. S. 1976. Handbook of North American birds, Vol. 3. Waterfowl (Part 2). Yale University Press, New Haven.

${ }^{5}$ PETERSON, R. T., GUY MOUNTFORT and P. A. D. HOLLOM. 1954. A field guide to the birds of Britain and Europe. Houghton Mifflin Co., Boston.

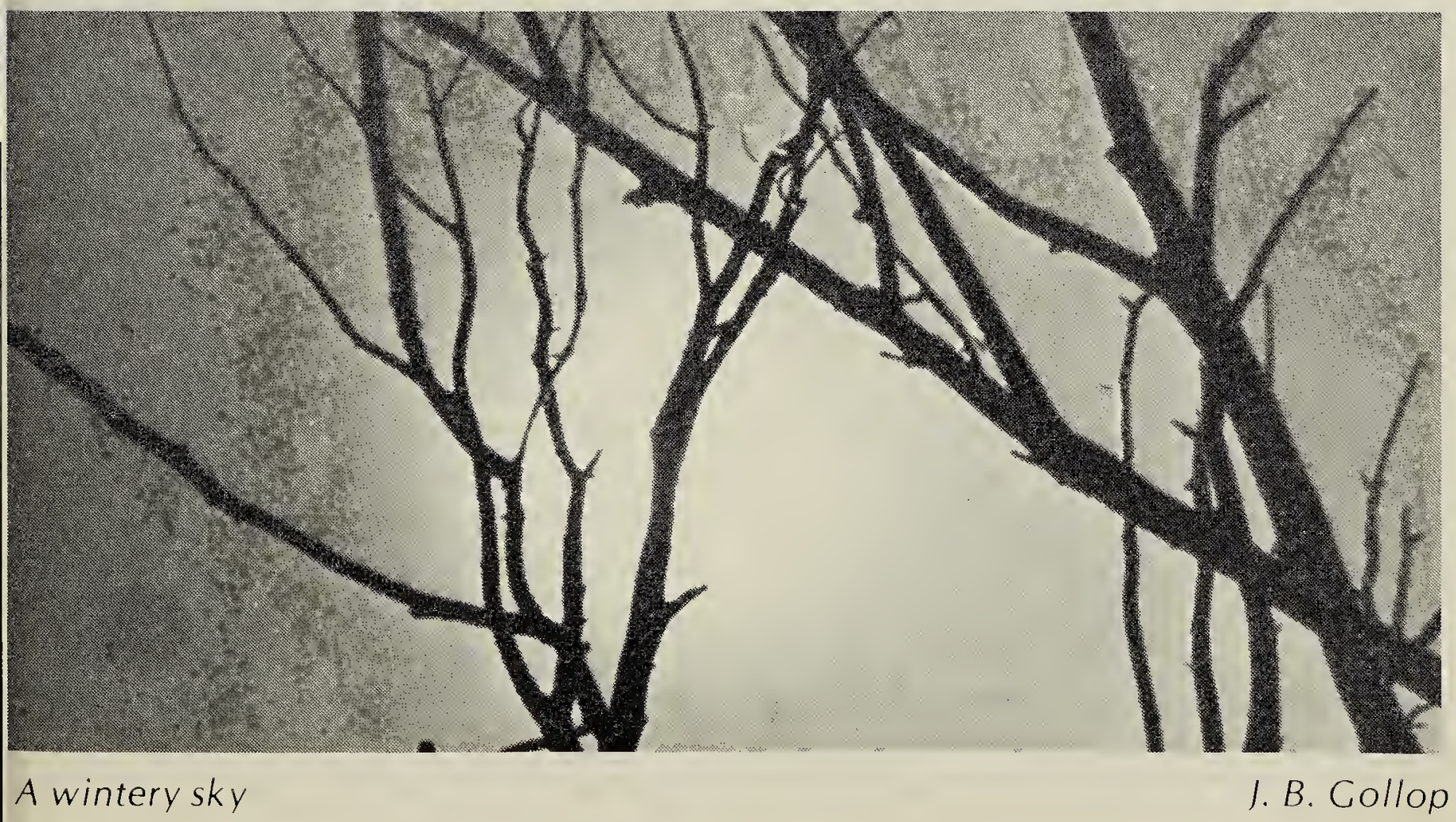

